\title{
Liquidity Trap in Developing Economy: The Case of CEMAC
}

\author{
Nkoulou Nkoulou Jean Louis \\ Laboratory of Applied Economics, Omar Bongo University, Libreville, Gabon \\ Email: nkouloujeanlouis@hotmail.com
}

How to cite this paper: Louis, N. N. J. (2021). Liquidity Trap in Developing Economy: The Case of CEMAC. Open Journal of Business and Management, 9, 3036-3052. https://doi.org/10.4236/ojbm.2021.96170

Received: September 3, 2021

Accepted: November 23, 2021

Published: November 26, 2021

Copyright $\odot 2021$ by author(s) and Scientific Research Publishing Inc. This work is licensed under the Creative Commons Attribution International License (CC BY 4.0).

http://creativecommons.org/licenses/by/4.0/ (c) (i) Open Access

\begin{abstract}
In the countries in transition, and more specifically those in the Cemac zone, the economies seem to present symptoms of a liquidity trap in recent years, as evidenced by sluggish economic growth, high unemployment and low demand. On the basis of hypotheses derived from a theoretical model, an empirical estimate was used. The results of the model indicate that this phenomenon exists in the Cemac area and that monetary policy is ineffective, and therefore its treatment can only be envisaged through innovative fiscal stabilisation and recovery policies aimed at boosting the private sector, on the one hand, and promote a participatory public policy materialized by the implementation of a decentralization of economic power to actors of civil society, the sector and local elected officials. Such a reform would aim to improve the effectiveness of public policies in a context of uncertainty and poverty.
\end{abstract}

\section{Keywords}

Asymmetric Shocks, Zero Inflation, Monetary Union, Adjustment Policy, International Balance, Economic Coordination, Cemac (Economic Community of Central African States)

\section{Introduction}

The mixed results of public policies to support the economy, were symbolized by the massive injection of liquidity to prevent the harmful effects of covid19 (Stiglitz, et al., 2020), but they are much more materialized by the announced regressions in economic growth rates coupled with forecasts of high unemployment rates in the advanced economies (Kleinfeld, 2020), combined with a very gradual impoverishment in the transition economies, put the economic policy debate back in a liquidity trap.

The concept of the liquidity trap, well present in the economic literature after 
the Great Depression of the 1930s, gradually fell into decline before making a comeback in theoretical and factual debates since Japan's "lost decade" (Paul Krugman et al., 1998; Gauti B. Eggertsson \& Michael Woodford, 2003; Ben S. Bernanke, Vincent R. Reinhart, \& Brian P. Sack, 2004).

On the theoretical level, two generations of non-exclusive debates are often put forward to circumscribe the debates around this concept. The first generation of debates revolves around the foundations of this phenomenon, while the second generation focuses on its consequences. With regard to the foundations of the concept of the liquidity trap, two theses crystallize the debates around the money supply, on the one hand, and by relying on interest rates, on the other.

Proponents of the money supply thesis base the liquidity trap on a situation in which the demand for speculative money becomes insatiable at the prevailing (minimum) interest rate. This situation undermines the effectiveness of money supply policies. Thus, any injection of money is absorbed in cash balances by agents. This analysis of the liquidity trap is sometimes considered to be the Keynesian reference situation (Romer, 2000).

For the proponents of the second thesis, on the other hand, the liquidity trap is presented as a situation in which long rates are completely disconnected from short rates. This situation often occurs in the case where all agents are forward-looking, and where the current interest rate no longer intervenes in their arbitrage between short and long securities. Uncertainty is such that no agent wishes to take a long position. Agents take refuge in liquidity, i.e. in short securities (and not in money), even if their yield falls drastically. Consequently, a policy of reducing short rates does not allow long rates to fall, and monetary policy becomes ineffective, not because rates cannot be lowered below a minimum rate, but because there is a disconnection between short rates and the cost of credit for investment (Villieu, 2004; Romer \& Romer, 2002).

As for the second generation of debates, focused on the consequences of the liquidity trap, the controversies seem to converge towards the concept of secular stagnation as the embodiment of the consequences of the liquidity trap. This concept actually reflects the persistence of the liquidity trap over time, the symptoms of which are manifested by a depression in the structural demand of the economy. In fact, it is a situation in which the natural interest rate that balances savings and investment becomes negative (Korinek \& Simsek 2014), and three causes are generally associated with its occurrence. The first relates to the ageing of the population, which leads to a preference for consumer spending to the detriment of investment. The second relates to income inequality, which explains a strong propensity to save on the part of households with financial capacity, which obviates the need for investment financing. The last cause, for its part, stems from the shock of debt reduction, which consists of agents paying their debt in order to give themselves a good debt capacity at the end of the adjustment (Artus, 2014).

On the empirical level, the liquidity trap to generate the debates on the means of getting out of such a vicious circle and the avenues of reflection have been 
oriented towards two complementary strategies centred on raising the inflation target on the one hand, and the taxation of money on the other.

For the fervent advocates of raising the inflation target, the strategy is for the central bank to make economic agents believe that it will sustainably maintain high inflation rates, and if agents believe then the economy should end up with lower real interest rates, and consequently an increase in investment spending by the private sector (Krugman, 2012; Blanchard et al., 2010).

As for the defenders of the idea of taxing currency, they advocate the payment of negative interest on the holding of reserves by the banks, and the application of such a measure aims to encourage the banks to facilitate credit to private agents in order to boost investment (Willem, 2009).

Theoretical and empirical debates reveal the interest of the analysis of the liquidity trap in an economy that is a member of a monetary zone facing asymmetric shocks and macroeconomic adjustment.

It is precisely then a matter of focusing on the economies of the Central African

Economic and Monetary Community (CEMAC) which, due to the occurence of the covid-19 health shock, are experiencing endemic impoverishment despite accommodative monetary policy demeasures and an expansionary fiscal policy. There are at least two reasons to justify such an option:

- reducing the monetary authorities; room for maneuver in macroeconomic adjustment;

- making fiscal policy pro-cyclical to the point of undermining the credibility of the public authorities.

CEMAC is composed of six states (Cameroon, Congo, Gabon, Equatorial Guinea, Central African Republic and Chad). This group of countries has small, highly extraverted economies based on the exploitation of mining, oil and timber products. As a result, this community is largely dependent on international market conditions, including commodity market shocks, financial crises and currently the global health crisis. In addition, its economies are also characterized by a precarious financing system due to the embryonic nature of the regional financial market, which exposes the area to financing constraint. As the currency is in fact the only lever of financing, and due to political, health and economic uncertainties, the CEMAC zone appears very vulnerable and raises fears of a liquidity trap.

This paper, focusing specifically on the Cemac zone, attempts to highlight the existence of a liquidity trap and to propose, in a practical way, the necessary adjustments. Therefore, in the rest of our work, we will first deal with the formation of the liquidity trap in the Cemac zone using a theoretical model (Part I), before proceeding to an empirical verification (Part II).

\section{Theoretical Analysis of the Liquidity Trap in the Cemac Zone}

We would first like to present the theoretical model before moving on to its 
characterization in the form of a game.

\subsection{Presentation of Hypothesis and Theoretical Model Articulation}

The aim is to formulate the hypotheses of the model well before presenting its articulation in the form of a game.

\section{Hypothesis}

This model, which is based on the work of Jeanne and Korinek (2010), considers a simplified open economy with two countries belonging to two monetary zones (African franc zone and euro zone) with two goods (rated d and e, for domestic and foreign).

Each country is populated by a representative agent that consumes both goods, with a preference for the good produced in its own country. The two countries are perfectly integrated both financially and commercially.

Production uses inputs made by a continuum of monopolistic producers who set their prices in advance. We consider the dynamic general equilibrium of the model with rational anticipations.

The main reference point for monetary policy is the "natural" real interest rate that would be observed if the economy were in a situation of full employment. Demand will tend to be insufficient (excessive) if the observed real interest rate is higher (lower) than the natural real interest rate.

\section{Model Articulation}

The starting point is a shock large enough to bring the natural interest rate down to a negative level. There are several ways to conceive of this shock. From the perspective of equality of savings and investment in a closed economy, the shock can consist of a large increase in the supply of savings or a decrease in the demand for investment.

In models with a representative consumer who optimizes an inter-temporal utility function, this type of shock appears as a form of Euler's equation for consumption, which can be written (Jeanne \& Korinek, 2010)

$$
\mathrm{e}^{\delta t} u^{\prime}\left(c_{t}\right)=\mathrm{e}^{t r-\gamma+\delta_{t+1}} u^{\prime}\left(c_{t+1}\right)
$$

where $\delta$ is a parameter representing the preference for the present at time $t, r t$ is the real interest rate between $t$ and $t+1$ and $y$ is the psychological discount rate of the consumer. After linearization we obtain:

$$
r_{t}=\gamma+\delta_{t}-\delta_{t+1}+\frac{g_{t+1}}{\varepsilon}
$$

where $g_{t+1}$ is the growth rate of full employment consumption between $t$ and $t$ +1 and $\varepsilon$ is the inter-temporal substitution elasticity of consumption. The natural interest rate can become negative if there is a negative demand shock (decline) or a drop in the rate of growth of anticipated consumption (which could reflect a decline in the rate of growth of productivity).

Being in a configuration of an interaction between the two zones, the de- 
mands of the two countries are expressed as follows in deviation:

$$
\begin{aligned}
& y=-a r+b r^{*}+\mu \\
& y^{*}=-a r^{*}+b r+\mu
\end{aligned}
$$

With, $y$ the demand for the goods, $r$ the nominal interest rate, and $\mu$ shocks to the economy.

Moreover, $a>b$, in other words, monetary policy has a more powerful effect at home than abroad. Consider the impact of a negative demand shock in the domestic country (covid19 health shock). Since prices are rigid at the time of the shock, the drop in demand can create underemployment in the short term. All other things being equal, the shock also reduces domestic imports, and is therefore transmitted to the foreign country.

What is the impact of this shock on natural interest rates in both countries?

This shock has massive macroeconomic implications, the first being a decline in demand and an increase in desired savings, as well as a reduction in the current account deficit. This is the moment when the phenomenon of "global over-saving", invoked by Bernanke (2005) to explain financial imbalances between zones, becomes truly global. All other things being equal, this shock should bring down the world natural real interest rate, perhaps to negative levels, given that real interest rates were already low before the crisis.

This new desire to save by Eurozone households, which should be sustainable, is also useful in that it puts the economies of both zones on a more sustainable path of debt accumulation. But it requires a delicate rebalancing of demand between the euro zone and the CEMAC zone.

This rebalancing of demand poses a new problem. Full employment, i.e. a policy of reducing unemployment, can only be achieved in the euro zone if the countries of the franc zone buy European products. However, even if the countries of the CEMAC zone are willing to increase their demand for European products because of the secular links, it turns out that the first effect of the covid19 crisis is to have a downward impact on their own demand.

At first glance, the covid19 shock seems to have put the world economy in a stalemate. Where will aggregate demand come from? At this stage of the analysis, it may be useful to advance in the light of a game model.

\subsection{Characterization and Outcome of the Game}

Starting from the assumption that, for a given level of autonomous deficit, there are two possible equilibrium interest rates in an economy, we would like to know which equilibrium interest rate the economy will converge towards following a fiscal shock induced by the covid-19 crisis. This is a question that we will ask ourselves.

The variables $r$ and $r^{*}$, are the real interest rates in the franc zone country and in the euro zone country. There is then a continuum of real interest rates that puts the domestic and foreign countries at full employment.

Assuming that the demand elasticity of the domestic country is greater than 1 , 
and if, starting from a situation of full employment, the domestic country raises its real interest rate, it is possible to restore full employment between the two zones by raising the real interest rate in the euro zone. This confirms the existence of multiple equilibrium in interest rates that are likely to lead to a sub-optimal situation generating underemployment. Everything depends on the strategic behavior of the monetary authorities in each zone.

We then assume a game with two players: the euro zone and the CEMAC zone. The euro zone has two possibilities: choose a low interest rate or a high interest rate. Similarly, the CEMAC zone also has two possibilities: choose a low interest rate or a high interest rate.

The gain in utility that each player makes depends not only on his or her own decision, but also on that of the other player. The strategic nature of the players' decisions indicates that this is a simultaneous game. And the non-cooperation between the ECB and the BEAC makes such a hypothesis plausible.

Given two players and two possible actions, the four different winning configurations can be represented in the following Table 1.

The payoff structure reveals that there are two pure strategy Nash equilibrium for this one-shot game: a high equilibrium (high real interest rate) where the euro zone and the franc zone agree on a high real rate equilibrium and a low equilibrium (low real interest rate) where they agree on a low-rate equilibrium. Similarly, the game can also lead to two strategies where each player records a loss $(-1,-1)$. Assuming rational players, such a strategy has been excluded.

What are in fact the implications of such a game? The main concern is which of the two balances is more likely to be achieved given the institutional structure (the rules and actors of the game) that define the nature of the final choice.

Now assume a negative shock on demand ( $\alpha$ ) in the Cemac zone following the fall in oil prices (due to the cessation of activity linked to the health crisis), the interest rate in the zone has fallen, which in turn has a recessive effect on the real interest rate in the euro zone, which is already facing a real fall in economic growth and an increase in unemployment.

Since the adjustment towards full employment cannot take place automatically because of the existence of nominal rigidities, it must be assisted by monetary policy. Because of the declared independence of the two central banks, there are exogenous inflation targets, which are noted as follows $\hat{\pi}$ and $\hat{\pi}$ symbolizing this autonomy.

Table 1. Structure of earnings.

\begin{tabular}{cccc}
\hline & BCE & \\
\hline & & $r_{E}^{*}$ & $r_{F}^{*}$ \\
BEAC & $r_{E}$ & 1 & -1 \\
& & 1 & -1 \\
& $r_{F}$ & -1 & 0 \\
& & -1 & 0
\end{tabular}




$$
\left\{\begin{array}{l}
r \geq-\hat{\pi} \\
r^{*} \geq-\hat{\pi}^{*}
\end{array}\right.
$$

Only as each monetary zone seeks to reduce unemployment while caring about its credibility, it is likely that such a demand shock will lead to a liquidity trap in both zones.

Thus, the demand shock will reduce natural interest rates to negative levels in both zones, and central banks will thus reduce their nominal interest rate close to zero, but this will not be enough to achieve full employment because expected inflation is too low.

There is underemployment, despite a very low nominal interest rate, in both currency zones the real interest rate is well above its natural level.

\section{Empirical Verification of the Liquidity Trap in the Cemac Zone}

To verify the existence of the liquidity trap in the Cemac zone, we rely on the work of Eggertsson and Krugman (2012) to proceed with the specification of the model, its estimation and the interpretation of the results obtained.

\subsection{Model Specification and Estimation}

The idea that in a liquidity trap situation, the movement of debt reduction generates a fall in production linked to the fall in demand, and a fall in prices; leads to a relationship between debt, on the one hand, and the components of demand and inflation, on the other.

Our model can then take the following form:

$$
D=f(I, C, \operatorname{Inf})
$$

With:

$D$, indebtedness,

I, public investment,

$C$, public consumption,

Inf, inflation.

Linearizing relation [5] with the logarithmic operator and taking into account the time factor, we obtain the following equation:

$$
D_{t}=\alpha_{1} I_{t}+\alpha_{2} C_{t}+\alpha_{3} I n f_{t}+\varepsilon_{t}
$$

By hypothesis, we will speak of a liquidity trap if $\alpha_{1}<0$ or $\alpha_{2}<0$ and $\alpha_{1}>\alpha_{2}$.

The model is estimated with annual data covering the period 1991-2018. All data are taken from the World DataBank (2019). For the estimation of equation [6]; we use the dynamic panel procedure with the ARDL method for two reasons. This allows more room for freedom, on the one hand, and on the other hand, it gives the possibility to deal with the dynamics of the term and the long term.

The results of the preliminary tests show that all the variables are integrated in 
first difference from the Levin, Lin and Chu (2002) tests, the Fischer heterogeneity test is very conclusive, and allows a treatment in panel data. Hausman's test indicates that our model corresponds to a fixed-effect model. Therefore, we carried out the cointegration test, which reveals the existence of a cointegrating relationship between debt, investment, consumption and inflation.

At the end of its preliminary testing procedures, we have estimated our model (Appendix 3), and the synthetic results are as Table 2.

The results show that the specification of equation [6] as an error-correction model is validated. The coefficient of the restoring force is significant and negative. Overall, it appears that Gabon's debt policy is weakly explained by consumer and investment spending. While in the long term investment and consumption strongly explain public debt, it seems to have a recessive effect on inflation and consumption.

Like $\alpha_{1}<0$ in the short term and $\alpha_{1}>\alpha_{2}$ in the long term, the Cemac zone shows clear signs of a liquidity trap.

Clearly, in the short term, the components of demand remain well below optimal in the ecmac zone, and this situation is explained by the spending reduction policies implemented by governments in recent years to adjust to the decline in government revenue, which is largely dependent on fluctuations in falling raw material prices....

And to regain the confidence of donors, the public authorities concerned have been engaged in a process of forced debt payment, creating a shock of debt reduction that not only weakened public accounts and corporate balance sheets, but above all accentuated the uncertainty that leads households to increase their savings to the detriment of consumption.

In fact, the accommodating monetary policy conducted by the Beac through its key rate and credit facilities to banks remains inoperative because banks are constrained not only by prudential ratios, but also by the desire to consolidate their balance sheet. The direct consequence is that bank lending to households remains sluggish and the contraction of credit to businesses reinforces the worrying decline in both consumption and investment, and ultimately in short-term demand in the CEMAC zone, as shown by the results of the modeling. Clearly, the economies of this monetary zone, already weakened by poverty and chronic budget deficits, show real signs of a liquidity trap.

Table 2. Summary of results.

\begin{tabular}{llll}
\hline & \multicolumn{3}{l}{ Explanatory variables } \\
Short term & $\mathrm{D}($ cons $)$ & $\mathrm{D}(\mathrm{Inf})$ & $\mathrm{D}(\mathrm{Inv})$ \\
Variable explained Debt & 0.8 & -0.28 & -0.28 \\
& $(1.23)$ & $(-1.15)$ & $(-0.34)$ \\
\hline \multirow{2}{*}{ Long term } & Cons & Inf & Inv \\
Variable explained Debt & -2.07 & -11 & 5.9 \\
& $(-1.96)$ & $(-2.7)$ & $(2.8)$ \\
\hline
\end{tabular}




\subsection{Interpretation of Findings}

According to the results of our model, the liquidity trap is indeed a short-term phenomenon in the economies of the Cemac zone. Thus, to get out of this trap, it is obvious that the economies concerned need to make a fiscal adjustment (Krugman Paul, 2012), particularly because the marginal social cost associated with public spending is still very low, since its economies are still underemployed (Nkoulou Nkoulou, 2008), on the one hand, and because private demand is far from sufficient to employ all resources, on the other hand.

The fiscal authorities can in fact use two levers to stabilize and revive the economy and thus get out of the liquidity trap without jeopardizing public finances. On the one hand, they must work to energize the private sector so that it can take over the creation of wealth and the fight against poverty, and on the other hand, they must generalize a public policy that participates in the policy of decentralization in order to make citizens economic actors at the service of their own social well-being.

First of all, the dynamization of the private sector, which requires the contribution of its expertise and access to its skills. Thus, the know-how of the private sector enhances the quality of the services offered as soon as it becomes a player in the provision of public goods, with the corollary of harmonizing remuneration systems that remove barriers between production systems and structures. Such expertise then makes it possible to focus on the development of new, more profitable and competitive products and services. Clearly, the public service is provided by a private partner at a lower cost, resulting in economies of scale.

As a follow-up to participatory public policy, this would involve a decentralization of powers between civil society, the private sector, scientists and local elected officials to facilitate the social acceptance of public decisions and thus make public action effective. Such a body would be an exchange of contributions, a language and a listening ear for the expectations and concerns of the various stakeholders so that the design, risk prevention and implementation of public policies lead to a convincing result in terms of the effectiveness of the fiscal stimulus policy.

\section{Recommendation}

This survey that we have just carried out shows that the economies of the CEMAC zone are well caught in the liquidity trap. The empirical model tested for this purpose indicates that this phenomenon is short-term and enshrines the ineffectiveness of monetary policy, and therefore can only be addressed by innovative fiscal stabilization and recovery policies that aim to boost the private sector on the one hand, and the promotion of a participatory public policy materialized by the implementation of a policy of decentralization of economic power to civil society actors, the public sector and local elected officials on the other. Such a reform would aim to improve the effectiveness of fiscal policy in a context of 
uncertainty and poverty.

To help the economies of the CEMAC zone escape the liquidity trap, two proposals seem effective, namely to implement innovative fiscal stabilization and recovery policies aimed at stimulating the private sector, on the one hand, and promoting a participatory public policy by implementing a policy of decentralization of economic power to civil society actors, the private sector and local elected officials. Such a reform would aim to improve the efficiency of fiscal policy in a context of fiscal policy in a context of uncertainty and poverty.

\section{Limitations of the Work}

This work has at least two limitations related to the methodology and recommendations. First, the methodology, as the CEMAC zone is composed of heterogeneous economies, it would have been better to do a country-by-country analysis and thus better highlight the specificities of each member economy of the zone. Second, the recommendations, being in the wake of the generalization of unconventional monetary policies, our monetary policies, our recommendations did not include this dimension. Our future research will move in this direction.

\section{Conflicts of Interest}

The author declares no conflicts of interest regarding the publication of this paper.

\section{References}

Artus (2014, April). The Euro Crisis, 2014. High School Meeting Day.

Bernanke, B. S. (2005). The Global Saving Glut and the U.S. Current Account Deficit. Econ Papers No. 77, Speech from Board of Governors of the Federal Reserve System (U.S.).

Bernanke, B. S., Reinhart, V. R., \& Sack, B. P. (2004). Monetary Policy Alternatives at the Zero Bound: An Empirical Assessment. Brookings Papers on Economic Activity, 2004, 1-100. https://doi.org/10.1353/eca.2005.0002

Blanchard, O., Das, M., \& Faruqee, H. (2010) The Initial Impact of the Crisis on Emerging Market Countries. Brookings Papers on Economic Activity, 2010, 263-307. https://doi.org/10.1353/eca.2010.0005

Eggertsson, G. B., \& Krugman, P. (2012). Debt, Deleveraging, and the Liquidity Trap: A Fisher-Minsky-Koo Approache. The Quarterly, Journal of Economics, 127, 1469-1513. https://doi.org/10.1093/qje/qj023

Eggertsson, G. B., \& Woodford, M. (2003). The Zero Bound on Interest Rates and Optimal Monetary Policy. Brookings Papers on Economic Activity, 2003, 139-211. https://doi.org/10.1353/eca.2003.0010

Jeanne, O., \& Korinek, A. (2010). Excessive Volatility in Capital Flows: A Pigouvian Taxation Approach. Working Papers No. 15927, National Bureau of Economic Research. https://doi.org/10.3386/w15927

Kleinfeld, R. (2020, March 31). Do Authoritarian or Democratic Country Handle Pandemics Better? CARNEGIE, Endowment for International Policy.

Korinek, A., \& Simsek, A. (2014). Liquidity Trap and Excessive Leverage. IMF Working Papers, 14, 49. https://doi.org/10.5089/9781498370943.001 
Krugman, P. (2012, April 29). End This Depression Now! Kirkus Reviews.

Krugman, P., Dominquez, K. M., \& Rogoff, K. (1998). It's Baaack: Japan's Slump and the Return of the Liquidity Trap. Brookings Papers on Economic Activity, 1998, 137-205. https://doi.org/10.2307/2534694

Levin, A., Lin, C.-F., \& Chu, C.-S. J. (2002). Unit Root Tests in Panel Data: Asymptotic and Finite Sample Properties. Journal of Econometrics, 108, 1-24. https://doi.org/10.1016/S0304-4076(01)00098-7

Nkoulou Nkoulou, J. L. (2008). Potential Growth. Economie et Gestion Review, 1, 34-46.

Romer, C. D., \& Romer, D. H. (2002). A Rehabilitation of Monetary Policy in the 1950's. American Economic Review, 92, 121-127. https://doi.org/10.1257/000282802320189113

Romer, D. (2000). Keynesian Macroeconomics without the LM Curve. Journal of Economic Perspectives, 14, 149-169. https://doi.org/10.1257/jep.14.2.149

Stiglitz, J. et al. (2020). Defeat the Big Bill. MF Finance \& Development.

Villieu, P. (2004). Macroeconomics without LM? A Summary Model for the Analysis of Short Term Policies. Political Economy Review, 114, 289-322. https://doi.org/10.3917/redp.143.0289

Willem, B. (2009). Lessons from the Global Financial Crisis for Regulators and Supervisors. FMG Discussion Papers dp 635, Financial Markets Group.

World DataBank (2019). https://databank.banquemondiale.org/ 


\section{Annexe 1. Tests Préliminaire}

Tests de racine unitaire

- Detpub

Null Hypothesis: Unit root (common unit root process)

Series: D(DTPUB)

Date: 09/26/20 Time: 13:13

Sample: 19912018

Exogenous variables: Individual effects

User-specified lags: 1

Newey-West automatic bandwidth selection and Bartlett kernel

Total (balanced) observations: 100

Cross-sections included: 4

\begin{tabular}{|c|c|c|c|c|c|c|c|}
\hline \multicolumn{4}{|l|}{ Method } & \multicolumn{2}{|l|}{ Statistic } & \multicolumn{2}{|c|}{ Prob. ${ }^{* *}$} \\
\hline \multicolumn{4}{|c|}{ Levin, Lin \& Chu $\mathrm{t}^{*}$} & \multicolumn{2}{|c|}{-5.17043} & \multicolumn{2}{|l|}{0.0000} \\
\hline \multicolumn{8}{|c|}{${ }^{* *}$ Probabilities are computed assuming asymptotic normality } \\
\hline \multicolumn{8}{|c|}{ Intermediate results on $\mathrm{D}(\mathrm{DTPUB})$} \\
\hline Cross & 2nd Stage & Variance & HAC of & & Max & Band- & \\
\hline section & Coefficient & of Reg & Dep. & Lag & Lag & width & Obs \\
\hline Gabon & -0.88720 & 138.68 & 39.339 & 1 & 1 & 7.0 & 25 \\
\hline Cameroun & -0.51217 & 43.374 & 23.654 & 1 & 1 & 5.0 & 25 \\
\hline Congo & -1.40641 & 754.46 & 74.654 & 1 & 1 & 25.0 & 25 \\
\hline \multirow[t]{2}{*}{ Tchad } & -1.68077 & 204.36 & 39.090 & 1 & 1 & 23.0 & 25 \\
\hline & Coefficient & $\mathrm{t}$-Stat & SE Reg & $\mathrm{mu}^{*}$ & $\operatorname{sig}^{*}$ & & Obs \\
\hline Pooled & -1.02848 & -7.892 & 1.078 & -0.554 & 0.919 & & 100 \\
\hline
\end{tabular}

- Cons

Null Hypothesis: Unit root (common unit root process)

Series: $\mathrm{D}(\mathrm{CONS})$

Date: 09/26/20 Time: 13:09

Sample: 19912018

Exogenous variables: Individual effects

User-specified lags: 1

Newey-West automatic bandwidth selection and Bartlett kernel

Total (balanced) observations: 50

Cross-sections included: 2 (2 dropped) 


\section{Continued}

\begin{tabular}{|c|c|c|c|c|c|c|c|}
\hline \multicolumn{4}{|l|}{ Method } & \multicolumn{2}{|l|}{ Statistic } & \multicolumn{2}{|l|}{ Prob. ${ }^{\star *}$} \\
\hline \multicolumn{4}{|c|}{ Levin, Lin \& Chu $\mathrm{t}^{*}$} & \multicolumn{2}{|l|}{-4.09755} & \multicolumn{2}{|l|}{0.0000} \\
\hline \multicolumn{8}{|c|}{${ }^{* *}$ Probabilities are computed assuming asymptotic normality } \\
\hline \multicolumn{8}{|c|}{ Intermediate results on $\mathrm{D}(\mathrm{CONS})$} \\
\hline Cross & 2nd Stage & Variance & HAC of & & Max & Band- & \\
\hline section & Coefficient & of Reg & Dep. & Lag & Lag & width & Obs \\
\hline Gabon & -1.81003 & 42.322 & 20.959 & 1 & 1 & 11.0 & 25 \\
\hline Camero & & \multicolumn{6}{|c|}{ Dropped from Test } \\
\hline Congo & & \multicolumn{6}{|c|}{ Dropped from Test } \\
\hline \multirow[t]{2}{*}{ Tchad } & -1.16964 & 1.0935 & 0.1910 & 1 & 1 & 15.0 & 25 \\
\hline & Coefficient & $\mathrm{t}$-Stat & SE Reg & $\mathrm{mu}^{*}$ & $\operatorname{sig}^{*}$ & & Obs \\
\hline Pooled & -1.43214 & -6.861 & 1.024 & -0.554 & 0.919 & & 50 \\
\hline
\end{tabular}

- Inf

Null Hypothesis: Unit root (common unit root process)

Series: D(INF)

Date: 09/26/20 Time: 13:16

Sample: 19912018

Exogenous variables: Individual effects

User-specified lags: 1

Newey-West automatic bandwidth selection and Bartlett kernel

Total number of observations: 99

Cross-sections included: 4

\begin{tabular}{|c|c|c|c|c|c|c|c|}
\hline \multicolumn{4}{|l|}{ Method } & \multicolumn{2}{|l|}{ Statistic } & \multicolumn{2}{|c|}{ Prob. ${ }^{* *}$} \\
\hline \multicolumn{4}{|c|}{ Levin, Lin \& Chu $\mathrm{t}^{\star}$} & \multicolumn{2}{|l|}{-9.09132} & \multicolumn{2}{|l|}{0.0000} \\
\hline \multicolumn{8}{|c|}{${ }^{*}$ Probabilities are computed assuming asymptotic normality } \\
\hline \multicolumn{8}{|c|}{ Intermediate results on $\mathrm{D}(\mathrm{INF})$} \\
\hline Cross & 2nd Stage & Variance & HAC of & & Max & Band- & \\
\hline section & Coefficient & of Reg & Dep. & Lag & Lag & width & Obs \\
\hline Gabon & -1.56222 & 77.930 & 17.204 & 1 & 1 & 11.0 & 25 \\
\hline Cameroun & -1.87562 & 73.347 & 10.839 & 1 & 1 & 18.0 & 25 \\
\hline Congo & -1.71417 & 90.281 & 10.095 & 1 & 1 & 22.0 & 24 \\
\hline \multirow[t]{2}{*}{ Tchad } & -2.12224 & 138.47 & 31.177 & 1 & 1 & 15.0 & 25 \\
\hline & Coefficient & t-Stat & SE Reg & $\mathrm{mu}^{*}$ & $\operatorname{sig}^{*}$ & & Obs \\
\hline Pooled & -1.81410 & -11.714 & 1.010 & -0.554 & 0.919 & & 99 \\
\hline
\end{tabular}


- Inv

Null Hypothesis: Unit root (common unit root process)

Series: D(INV)

Date: 09/26/20 Time: 13:18

Sample: 19912018

Exogenous variables: Individual effects

User-specified lags: 1

Newey-West automatic bandwidth selection and Bartlett kernel

Total (balanced) observations: 100

Cross-sections included: 4

\begin{tabular}{|c|c|c|c|c|c|c|c|}
\hline \multicolumn{4}{|l|}{ Method } & \multicolumn{2}{|l|}{ Statistic } & \multicolumn{2}{|c|}{ Prob.** } \\
\hline \multicolumn{4}{|c|}{ Levin, Lin \& Chu $\mathrm{t}^{*}$} & \multicolumn{2}{|l|}{-5.92184} & \multicolumn{2}{|l|}{0.0000} \\
\hline \multicolumn{8}{|c|}{${ }^{\star *}$ Probabilities are computed assuming asymptotic normality } \\
\hline \multicolumn{8}{|c|}{ Intermediate results on $\mathrm{D}(\mathrm{INV})$} \\
\hline Cross & 2nd Stage & Variance & HAC of & & $\operatorname{Max}$ & Band- & \\
\hline section & Coefficient & of Reg & Dep. & Lag & Lag & width & Obs \\
\hline Gabon & -1.86249 & 30.565 & 9.7391 & 1 & 1 & 8.0 & 25 \\
\hline Cameroun & -0.75983 & 2.0415 & 0.2384 & 1 & 1 & 25.0 & 25 \\
\hline Congo & -1.33595 & 4.0844 & 0.6254 & 1 & 1 & 14.0 & 25 \\
\hline \multirow[t]{2}{*}{ Tchad } & -0.95739 & 7.5633 & 1.0980 & 1 & 1 & 12.0 & 25 \\
\hline & Coefficient & $\mathrm{t}$-Stat & SE Reg & $\mathrm{mu}^{*}$ & $\operatorname{sig}^{*}$ & & Obs \\
\hline Pooled & -1.23093 & -8.511 & 1.047 & -0.554 & 0.919 & & 100 \\
\hline
\end{tabular}

Résultats du test d'hétérogénéité de Fischer

Redundant Fixed Effects Tests

Equation: Untitled

Test cross-section fixed effects

\begin{tabular}{llll}
\hline Effects Test & Statistic & d.f. & Prob. \\
\hline Cross-section F & 16.824468 & $(3,104)$ & 0.0000 \\
Cross-section Chi-square & 43.915046 & 3 & 0.0000 \\
\hline
\end{tabular}

Cross-section fixed effects test equation:

Dependent Variable: DTPUB

Method: Panel Least Squares

Date: 09/26/20 Time: 13:27

Sample: 19912018

Periods included: 28

Cross-sections included: 4

Total panel (unbalanced) observations: 111 


\section{Continued}

\begin{tabular}{lllcl}
\hline Variable & Coefficient & Std. Error & t-Statistic & Prob. \\
\hline CONS & 0.386897 & 0.221515 & 1.746599 & 0.0836 \\
INF & -0.133024 & 0.715275 & -0.185976 & 0.8528 \\
INV & -5.333837 & 0.755541 & -7.059623 & 0.0000 \\
C & 140.8204 & 19.21583 & 7.328358 & 0.0000 \\
\hline R-squared & 0.373836 & Mean dependent var & 77.41839 \\
Adjusted R-squared & 0.356280 & S.D. dependent var & 76.90223 \\
S.E. of regression & 61.70032 & Akaike info criterion & 11.11783 \\
Sum squared resid & 407341.5 & Schwarz criterion & 11.21547 \\
Log likelihood & -613.0394 & Hannan-Quinn criter. & 11.15744 \\
F-statistic & 21.29392 & Durbin-Watson stat & 0.227798 \\
Prob(F-statistic) & 0.000000 & & \\
\hline
\end{tabular}

Résultats du test de cointégration

Pedroni Residual Cointegration Test

Series: DTPUB CONS INF INV

Date: 10/23/20 Time: $16: 08$

Sample: 19912018

Included observations: 112

Cross-sections included: 4

Null Hypothesis: No cointegration

Trend assumption: Deterministic intercept and trend

Automatic lag length selection based on SIC with a max lag of 5

Newey-West automatic bandwidth selection and Bartlett kernel

Alternative hypothesis: common AR coefs. (within-dimension)

\begin{tabular}{lllll}
\hline & \multicolumn{3}{c}{ Weighted } \\
\cline { 2 - 5 } & $\underline{\text { Statistic }}$ & $\underline{\text { Prob. }}$ & $\underline{\text { Statistic }}$ & Prob. \\
\hline Panel v-Statistic & 1.408679 & 0.0795 & 0.475092 & 0.3174 \\
Panel rho-Statistic & -0.345377 & 0.3649 & 0.252821 & 0.5998 \\
Panel PP-Statistic & -2.167521 & 0.0151 & -1.063443 & 0.1438 \\
Panel ADF-Statistic & -2.494619 & 0.0063 & -1.448242 & 0.0738 \\
\hline
\end{tabular}

Alternative hypothesis: individual AR coefs. (between-dimension)

\begin{tabular}{lll}
\hline & $\underline{\text { Statistic }}$ & Prob. \\
\hline Group rho-Statistic & 0.620651 & 0.7326 \\
Group PP-Statistic & -1.233750 & 0.1086 \\
Group ADF-Statistic & -1.551252 & 0.0604 \\
Cross section specific results & & \\
\hline
\end{tabular}




\section{Continued}

\begin{tabular}{llllll}
\hline \multicolumn{7}{l}{ Phillips-Peron results (non-parametric) } \\
\hline Cross ID & AR(1) & Variance & HAC & Bandwidth & Obs \\
\hline Gabon & 0.083 & 92.58379 & 88.97043 & 3.00 & 27 \\
Cameroun & 0.817 & 65.28135 & 126.9218 & 3.00 & 27 \\
Congo & 0.195 & 699.1484 & 699.1484 & 0.00 & 27 \\
Tchad & 0.447 & 118.2588 & 132.6822 & 1.00 & 27
\end{tabular}

Augmented Dickey-Fuller results (parametric)

\begin{tabular}{llllll}
\hline Cross ID & AR(1) & Variance & Lag & Max lag & Obs \\
\hline Gabon & 0.083 & 92.58379 & 0 & 5 & 27 \\
Cameroun & 0.736 & 43.17183 & 2 & 5 & 25 \\
Congo & 0.195 & 699.1484 & 0 & 5 & 27 \\
Tchad & 0.447 & 118.2588 & 0 & 5 & 27 \\
\hline
\end{tabular}

Résultats du test de Hausman

Correlated Random Effects-Hausman Test

Equation: Untitled

Test period random effects

\begin{tabular}{lllll}
\hline Test Summary & \multicolumn{2}{l}{ Chi-Sq. Statistic Chi-Sq. d.f. } & Prob. \\
\hline Period random & 40.797122 & 3 & 0.0000 \\
\hline \multicolumn{2}{l}{ Period random effects test comparisons: } & & & \\
\hline Variable & Fixed & Random & Var(Diff.) & Prob. \\
\hline INV & -1.942644 & -5.678710 & 0.364228 & 0.0000 \\
INF & -0.342095 & 0.111596 & 0.185995 & 0.2928 \\
CONS & -0.448259 & 3.849801 & 0.713932 & 0.0000
\end{tabular}

Period random effects test equation:

Dependent Variable: DTPUB

Method: Panel Least Squares

Date: 09/26/20 Time: 13:58

Sample: 19912018

Periods included: 28

Cross-sections included: 4

Total panel (balanced) observations: 112

\begin{tabular}{lllll}
\hline Variable & Coefficient & Std. Error & t-Statistic & Prob. \\
\hline C & 130.5181 & 57.10516 & 2.285575 & 0.0250 \\
INV & -1.942644 & 0.975918 & -1.990581 & 0.0500 \\
INF & -0.342095 & 0.689785 & -0.495944 & 0.6213 \\
CONS & -0.448259 & 1.232875 & -0.363588 & 0.7171 \\
\hline
\end{tabular}




\section{Continued}

Effects Specification

Cross-section fixed (dummy variables)

Period fixed (dummy variables)

\begin{tabular}{llll}
\hline R-squared & 0.819851 & Mean dependent var & 76.87123 \\
Adjusted R-squared & 0.743634 & S.D. dependent var & 76.77373 \\
S.E. of regression & 38.87255 & Akaike info criterion & 10.40381 \\
Sum squared resid & 117863.8 & Schwarz criterion & 11.22907 \\
Log likelihood & -548.6132 & Hannan-Quinn criter. & 10.73864 \\
F-statistic & 10.75680 & Durbin-Watson stat & 0.221079 \\
Prob(F-statistic) & 0.000000 & &
\end{tabular}

\section{Annexe 2. Estimation du Modèle}

Dependent Variable: D(DTPUB)

Method: ARDL

Date: 09/26/20 Time: 18:16

Sample: 19952018

Included observations: 96

Dependent lags: 4 (Fixed)

Dynamic regressors (1 lag, fixed): CONS INF INV

Fixed regressors:

\begin{tabular}{lllcl}
\hline Variable & Coefficient & Std. Error & t-Statistic & Prob. $^{*}$ \\
\hline & \multicolumn{2}{l}{ Long Run Equation } & & \\
\hline CONS & -2.079231 & 1.058749 & -1.963857 & 0.0530 \\
INF & -11.35289 & 4.125199 & -2.752082 & 0.0073 \\
INV & 5.958961 & 2.098701 & 2.839356 & 0.0057 \\
\hline & Short Run Equation & & \\
\hline COINTEQ01 & -0.072255 & 0.035663 & -2.026054 & 0.0461 \\
D(DTPUB(-1)) & 0.009898 & 0.164276 & 0.060251 & 0.9521 \\
D(DTPUB(-2)) & -0.059192 & 0.154088 & -0.384140 & 0.7019 \\
D(DTPUB(-3)) & -0.149559 & 0.085309 & -1.753137 & 0.0834 \\
D(CONS) & 0.878858 & 0.714025 & 1.230851 & 0.2219 \\
D(INF) & -0.285186 & 0.247978 & -1.150044 & 0.2535 \\
D(INV) & -0.281304 & 0.812586 & -0.346184 & 0.7301 \\
\hline Mean dependent var & -5.837037 & S.D. dependent var & 15.38496 \\
S.E. of regression & 12.01872 & Akaike info criterion & 6.479138 \\
Sum squared resid & 11700.42 & Schwarz criterion & 7.231580 \\
Log likelihood & -331.8317 & Hannan-Quinn criter. & 6.784428 \\
\hline
\end{tabular}

${ }^{\star}$ Note: p-values and any subsequent tests do not account for model selection. 